\title{
PERAN BRAND EQUITY MEMEDIASI WOM DAN MARKETING COMMUNICATION DENGAN MINAT BELI PRODUK OPPO
}

\author{
Ni Putu Nanda Pradnya Putri ${ }^{1}$ \\ I Gde Ketut Warmika
}

\author{
${ }^{1,2}$ Fakultas Ekonomi dan Bisnis Universitas Udayana, Bali, Indonesia \\ email: nandapradnyak18@gmail.com
}

\begin{abstract}
ABSTRAK
Penyampaian WOM dan marketing communication yang baik dapat meningkatkan brand equity produk yang akhirnya dapat menciptakan minat beli konsumen terhadap suatu produk. Penelitian ini bertujuan untuk mengetahui pengaruh WOM dan marketing communication terhadap minat beli melalui brand equity sebagai pemediasi. Sampel penelitian ditetapkan sebanyak 160 responden dengan menggunakan teknik pengambilan sampel yaitu purposive sampling. Teknik analisis yang digunakan adalah path analysis dengan uji asumsi klasik dan Uji Sobel. Penelitian ini diharapkan dapat memberikan kontribusi empiris tentang pengaruh antara variabel WOM, marketing communication, brand equity, dan minat beli bagi perkembangan ilmu pengetahuan dan menjadi bahan pertimbangan manajemen perusahaan. Hasil penelitian menunjukkan bahwa WOM dan marketing communication berpengaruh positif dan signifikan terhadap minat beli. Brand equity, WOM, dan marketing communication berpengaruh positif dan signifikan terhadap minat beli. Brand equity secara positif dan signifikan memediasi pengaruh WOM dan marketing communication terhadap minat beli.
\end{abstract}

Kata kunci: WOM, marketing communication, brand equity, minat beli

\begin{abstract}
Submission of good WOM and marketing communication can increase product brand equity which ultimately can create consumer buying interest in a product. This study aims to determine the effect of WOM and marketing communication on buying interest through brand equity as a mediator. The research sample was determined as many as 160 respondents using a sampling technique that is purposive sampling. The analysis technique used is path analysis with the classic assumption test and the Sobel Test. This research is expected to contribute empirically about the influence between WOM variables, marketing communication, brand equity, and buying interest for the development of science and become a consideration for company management. The results showed that WOM and marketing communication had a positive and significant effect on buying interest. Brand equity, WOM, and marketing communication have a positive and significant effect on buying interest. Brand equity positively and significantly mediates the effect of WOM and marketing communication on buying interest.
\end{abstract}

Keywords: WOM, marketing communication, brand equity, buying interest 


\section{PENDAHULUAN}

Persaingan global saat ini menuntut perusahaan untuk saling bersaing dalam memasarkan serta menjual produknya. Perusahaan harus mampu membuat produknya tetap bertahan dan tetap dikonsumsi oleh konsumen dalam jangka waktu yang lama. Konsumen saat ini juga sangat kritis dalam memilih suatu produk, keputusan untuk membeli suatu produk sangat dipengaruhi oleh penilaian akan kualitas produk tersebut (Prawira \& Yasa, 2014).

Ada banyak jenis smartphone yang sedang booming di zaman sekarang, salah satunya adalah Oppo. OPPO Electronic Corp, Ltd berdiri pada tahun 2004 sebagai produsen elektronik yang beralamat di Dongguan, Guangdong, China. Sebelum merambah ke teknologi Mobile smartphone, OPPO memproduksi peralatan elektronik seperti MP3 Player, LCD TV, Portable Media Player, DVD, e-Book dan Disc Player. Pada tahun 2008 OPPO mulai menggarap pasar Smartphone dengan menciptakan produk OPPO smartphone. Pada bulan April tahun 2013 OPPO pertama kalinya berada di pasar Indonesia secara resmi. Sebelum produknya di pasarkan ke Indonesia, OPPO terlebih dahulu melebarkan sayapnya ke beberapa negara seperti, Thailand, Vietnam, Rusia, Amerika dan Qatar. Sejak saat itu OPPO terus melakukan promosi memperkenalkan kualitas brand nya melalui iklan media cetak, TV, internet dan lain-lain. Produk unggulan smartphone OPPO adalah Oppo Find 5, Oppo Find Way U7015, dan OPPO Find Piano.

Semakin lama, produk Oppo semakin berkembang, adapun 10 produk keluaran Oppo yang terbaru pada tahun 2019 yaitu Oppo R11 Pro yang di rilis pada bulan Maret, Oppo F11 yang juga di rilis pada bulan Maret, Oppo R17 Pro, Oppo A7, Oppo A9, Oppo A3s, Oppo Find X, Oppo A3, Oppo F7 Youth, Oppo R15 Pro. Berikut data penjualan smartphone Oppo menurut www.topbrandaward.com:

Tabel 1.

Top Brand Index Smartphone 2015

\begin{tabular}{|c|c|c|}
\hline No & Merek & TBI (\%) \\
\hline 1 & Samsung & 29,7 \\
\hline 2 & Blackberry & 24,7 \\
\hline 3 & Nokia & 16,7 \\
\hline 4 & Iphone & 4,5 \\
\hline 5 & Smartfren & 3,8 \\
\hline 6 & Cross & 3,0 \\
\hline 7 & Advan & 2,9 \\
\hline 8 & Mito & 2,5 \\
\hline 9 & Lenovo & 2,4 \\
\hline 10 & Oppo & 2,2 \\
\hline
\end{tabular}

Sumber: Top Brand Award, 2015

Tabel 1. menunjukkan tingkat penjualan smartphone dari tahun 2015. Terlihat diantara 10 brand smartphone, Oppo berada di peringkat 10 dengan tingkat top brand index (TBI) sebesar 2,2\%. 
Tabel 2.

Top Brand Index Smartphone 2016

\begin{tabular}{|c|c|c|}
\hline No & Merek & TBI (\%) \\
\hline 1 & Samsung & 43,4 \\
\hline 2 & Nokia & 10,9 \\
\hline 3 & Blackberry & 9,8 \\
\hline 4 & Iphone & 5,8 \\
\hline 5 & Smartfren & 5,4 \\
\hline 6 & Lenovo & 4,0 \\
\hline 7 & Oppo & 3,4 \\
\hline 8 & Asus & 3,3 \\
\hline
\end{tabular}

Tabel 2. menunjukkan tingkat penjualan smartphone dari tahun 2016. Terlihat diantara 8 brand smartphone, Oppo berada di peringkat 7 dengan tingkat TBI 3,4\%. Ini menunjukkan bahwa terdapat peningkatan TBI pada produk Oppo dibandingkan dengan tahun 2015.

Tabel 3.

Top Brand Index Smartphone 2017

\begin{tabular}{|c|c|c|}
\hline No & Merek & TBI (\%) \\
\hline 1 & Samsung & 46,4 \\
\hline 2 & Nokia & 8,8 \\
\hline 3 & Blackberry & 8,0 \\
\hline 4 & Iphone & 5,1 \\
\hline 5 & Smartfren & 5,1 \\
\hline 6 & Lenovo & 4,4 \\
\hline 7 & Oppo & 4,1 \\
\hline 8 & 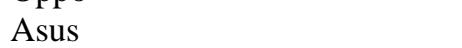 & 3,8 \\
\hline
\end{tabular}

Tabel 3. menunjukkan tingkat penjualan smartphone dari tahun 2017. Terlihat diantara 8 brand smartphone, Oppo tetap berada di peringkat 7, namun berbeda dengan tingkat TBI di tahun 2016 yang sebesar 3,4\%, di tahun 2017 tingkat TBI Oppo meningkat menjadi 4,1\%.

Tabel 4.

Top Brand Index Smartphone 2018

\begin{tabular}{|c|c|c|}
\hline No & Merek & TBI (\%) \\
\hline 1 & Samsung & 48,6 \\
\hline 2 & Oppo & 11,2 \\
\hline 3 & Xiomi & 5,5 \\
\hline 4 & Lenovo & 4,5 \\
\hline 5 & Nokia & 4,3 \\
\hline
\end{tabular}

Tabel 4. terlihat jelas bahwa pada tahun 2018 smartphone Oppo menduduki peringkat kedua pada jajaran merek smartphone pada website top brand award dengan TBI 11,2\%. Dilihat dari tingkat TBI tahun-tahun sebelumnya, tahun 2018 
merupakan tahun dimana tingkat TBI produk Oppo mencapai nilai tertingginya. Pada tabel-tabel tersebut, terlihat perkembangan produk smartphone Oppo meningkat setiap tahunnya. Oppo memiliki fitur lengkap yang hampir sama dengan Samsung, namun Samsung masih menduduki posisi teratas di Top Brand Index Smartphone tiap tahunnya. Dengan lengkapnya fitur dari Oppo, dan meningkatnya penjualan produk Oppo di setiap tahunnya, maka dari itu Oppo memiliki peluang untuk menduduki peringkat pertama pada Top Brand Index Smartphone dan berpeluang untuk meningkatkan minat beli dari calon konsumennya.

Minat beli merupakan tahapan dimana konsumen baru akan melakukan pembelian terhadap suatu produk, ini menjadi penting karena dengan adanya minat beli dari konsumen, dapat berpeluang besar bagi produk tersebut untuk dibeli dan meningkatkan penjualannya, namun ketika minat beli menurun, artinya ada sesuatu yang salah terhadap produk dan perusahaan harus cepat mencari tahu permasalahan dari penyebab menurunnya minat beli, karena akan dapat berakibat fatal bagi perusahaan ketika minat beli konsumen menurun terhadap produk yang dijualnya. Minat beli merupakan alat ukur yang efektif untuk memprediksi proses membeli (Mirabi et al., 2015).

Minat beli merupakan kecenderungan konsumen untuk membeli suatu merek atau mengambil tindakan yang berhubungan dengan pembelian yang diukur dengan tingkat kemungkinan konsumen melakukan pembelian (Moniaga dkk., 2017). Minat beli dapat diwujudkan apabila memenuhi kriteria yang pelanggan inginkan (Bougenvile \& Ruswanti, 2017). Banyak faktor yang mempengaruhi niat konsumen saat memilih produk dan keputusan akhir tergantung pada niat konsumen dengan faktor-faktor eksternal yang besar (Younus et al., 2015). Perusahaan hendaknya lebih cermat dalam memilih strategi bersaing agar mendapatkan perhatian lebih dari konsumen sehingga dapat meningkatkan minat beli dari konsumen untuk melakukan pembelian pada produk yang dijual. Perusahaan dapat menggunakan berbagai cara untuk meningkatkan minat beli konsumen terhadap produknya. Meningkatkan brand equity, mengembangkan WOM atau word of mouth yang positif di kalangan masyarakat, serta meningkatkan strategi pemasaran mereka melalui marketing communication dapat meningkatkan minat beli terhadap produk.

Perusahaan yang mampu membangun merek yang kuat di pikiran pelanggan, akan mampu menimbulkan minat beli konsumen terhadap produk dengan merek tersebut (Dewa, 2015). Brand atau merek adalah elemen kunci didalam hubungan perusahaan dengan konsumen. Brand merepresentasikan persepsi dan perasaan konsumen terhadap produk dan juga performanya, semua tentang produk atau jasa yang dimaksudkan untuk konsumen. Ekuitas merek dapat tercermin dalam cara konsumen berpikir, merasa, bertindak (dalam hubungannya dengan merek), harga, pangsa pasar, dan profitabilitas yang diberikan merek bagi perusahaan (Dewa, 2015). Brand equity merupakan suatu nilai yang dimiliki suatu merek dengan mengacu pada kekuatan nilai merek dalam mendorong tumbuhnya kesadaran konsumen mengenai keberadaan merek, asosiasi terhadap merek tersebut, persepsi mengenai kualitas merek, loyalitas 
konsumen terhadap merek, serta aset lainnya seperti hak paten, merek dagang dan jaringan distribusi (Aditya \& Wardana, 2017).

Brand equity mencerminkan semakin kuat sebuah merek, kemasan, dan kualitas dari produk tersebut, maka semakin kuat pula brand equity dari produk tersebut. Brand equity yang kuat pada suatu produk, membuat nama dari produk tersebut menguat di benak konsumen dan mendapatkan respon positif dari konsumen. Brand equity dipengaruhi oleh kebiasaan secara turun menurun dari brand awareness, brand association, perceived quality dan juga brand loyalty (Viliaus \& Tobing, 2017). Brand awareness atau kesadaran merek merupakan langkah pertama untuk membangun keakraban dengan merek yang bertindak sebagai sinyal kepercayaan di benak konsumen untuk mempertimbangkan merek yang berharga untuk dibeli, brand association merupakan sumber positioning produk dan diferensiasi untuk perusahaan di pasar, perceived quality merupakan kualitas yang akan dirasakan oleh konsumen, semakin tinggi kualitas yang dirasakan maka semakin tinggi pula ekuitas merek tersebut, brand loyalty merupakan dimensi terpenting dari brand equity karena mencerminkan komitmen dari konsumen untuk mengkonsumsi produk atau jasa secara berulang (Shah et al., 2016). Loyalitas merek dan kesadaran merek yang merupakan dimensi dari brand equity tidak memiliki pengaruh yang signifikan terhadap minat beli konsumen (Walangitan et al., 2015). Seluruh dimensi brand equity mempengaruhi minat beli produk. Keempat variabel tersebut berhubungan erat dengan brand equity, karena ketika keempat dimensi tersebut meningkat, maka brand equity dari suatu produk akan semakin baik (Aydin \& Ulengin, 2015). Asosiasi merek memiliki tingkat daya tertentu dan akan menjadi lebih kuat terhadap pengalaman konsumen pada suatu merek tertentu (Bougenvile \& Ruswanti, 2017). Brand equity mampu mendukung pengaruh loyalitas konsumen terhadap suatu produk dengan dorongan periklanan yang baik serta pelayanan yang maksimal (Budiarti et al., 2013). Perusahaan yang mampu membangun merek yang kuat di pikiran pelanggan, akan mampu menimbulkan niat beli konsumen terhadap produk dengan merek tersebut (Dewa, 2015). Semakin kuat ekuitas merek suatu produk, semakin kuat pula niat konsumen untuk mengkonsumsi produk tersebut yang selanjutnya dapat menggiring konsumen untuk melakukan pembelian serta mengantarkan perusahaan untuk meraup keuntungan dari waktu ke waktu (Dewa, 2015). Pengaruh dari brand equity yang besar terhadap minat beli konsumen, membuat brand equity digunakan sebagai variabel mediasi dari WOM dan marketing communication.

Banyak perusahaan di zaman sekarang menggunakan WOM pada pemasaran produknya yang dikenal juga sebagai marketing buzz untuk menyebarkan kalimat yang baik kepada pelanggan potensial (Wong et al., 2015). Data statistik menunjukkan bahwa pelanggan yang puas akan memberitahu ratarata sekitar dua belas orang, yang pada gilirannya akan memberitahu orang lain, ini akan menghasilkan dampak yang jelas dapat sangat merugikan perusahaan yang bertanggung jawab untuk pengalaman tersebut (Zaynutdinova \& Premysl, 2017). Adanya WOM maka perusahaan dapat membuat konsumen penasaran sehingga akan timbul minat beli konsumen tersebut pada produk yang dimaksud. Sehingga dalam sudut pandang terbaru, posisi diyakini semakin kuat menciptakan 
minat beli konsumen, sedangkan komunikasi pemasaran menjadi faktor yang dapat mempengaruhi WOM terhadap minat beli konsumen.

Faktor kedua setelah brand equity yang dapat meningkatkan minat beli yaitu WOM. WOM adalah suatu tindakan yang dilakukan oleh konsumen dalam memberikan informasi secara pribadi kepada sesama konsumen lain berkaitan dengan suatu produk ataupun jasa (Aditya \& Wardana, 2017). Alasan WOM penting dalam meningkatkan minat beli konsumen karena WOM lebih mudah dipercaya karena persepsi yang diutarakan secara langsung bersifat nyata dan berdasarkan pengalaman pribadi, sehingga yang mendengarkan dapat lebih mudah percaya dengan apa yang dikatakan dan memiliki minat untuk membeli produk tersebut. Variabel WOM berpengaruh signifikan terhadap variabel minat beli dengan koefisien jalur beta sebesar 0,664 (Putri et al., 2016). WOM berdampak positif pada minat beli konsumen (Khan, Ramzan, Shoaib, \& Mohyuddin, 2015). Setelah WOM, faktor lain yang dapat meningkatkan minat beli adalah marketing communication.

Marketing communication merupakan interaksi antara produsen dengan calon pelanggan atau pelanggan melalui beberapa media terpilih (Moniaga et al., 2017). Marketing communication merupakan kegiatan interaksi langsung antara pihak perusahaan kepada konsumen mereka. Tujuan dari dilakukannya marketing communication agar produk yang akan dipasarkan mendapatkan perhatian lebih dari konsumen sehingga konsumen mendapatkan dorongan untuk melakukan tindakan pembelian. Marketing communication berperan untuk membangun ikatan emosional terhadap merek dan seluruh atributnya kepada konsumen. Proses marketing communication diawali dengan komunikasi internal terhadap produk pada semua yang terlibat dalam proses produksi. Karyawan disemua tingkatan harus memahami dengan baik segala atribut perusahaan dan produk perusahaan sehingga dapat menjelaskan produknya dengan lebih baik dan mendetail. Semua dimensi marketing communication, hanya iklan yang berpengaruh negatif terhadap minat beli (Ering \& Pandowo, 2015). Komunikasi pemasaran memberikan pengaruh yang positif dan signifikan terhadap minat beli (Moniaga et al., 2017). Penggunaan marketing communication tools yang tepat, perusahaan yang berperan sebagai komunikator dapat dengan baik memperkenalkan dan memasarkan barang atau jasanya kepada konsumen selaku komunikan. Marketing communication mampu berkontribusi pada ekuitas merek dengan menyusun brand image dan melekatkan brand awareness dalam benak konsumen (Indriani, 2017).

Komunikator dalam WOM akan berperan sangat penting untuk dapat berkomunikasi secara optimal. Pada dasarnya WOM akan timbul secara alami pada saat individu memiliki rasa senang terhadap sebuah produk atas kepuasan yang telah didapat dari produk tersebut sehingga menciptakan perilaku yang mendorong, mengajak atau menyarankan individu lain untuk menggunakan produk yang sama (Putri et al., 2016). Penelitian oleh (Malino, 2015) menyatakan bahwa WOM terhadap dimensi brand equity berpengaruh negatif signifikan. Penelitian oleh (Armelini, 2011) menyatakan bahwa hanya efek kesadaran merek yang signifikan. Penelitian oleh (Sulistyowati et al., 2014) menyatakan bahwa WOM berpengaruh positif terhadap ekuitas merek. Penelitian oleh (Fenanda \& 
Solekah, 2018) menyatakan bahwa 4 dari 5 dimensi word of mouth diantaranya talkers, topics, takingpart dan tracking berpengaruh langsung terhadap brand equity, sedangkan 1 dimensi yaitu tools tidak berpengaruh langsung terhadap brand equity. Berdasarkan hal-hal diatas dan berdasarkan penelitian sebelumnya, maka rumusan hipotesis yang dapat diajukan yaitu :

$\mathrm{H}_{1}$ : WOM berpengaruh positif dan signifikan terhadap brand equity pada smartphone Oppo di Kota Denpasar

Komunikasi pemasaran merupakan cara atau teknik pemasaran dari perusahaan untuk memperkenalkan produknya kepada konsumen. Komunikasi pemasaran dilakukan oleh perusahaan agar produk yang akan dijual dapat tersampaikan pada konsumen, sehingga konsumen mengetahui tentang spesifikasi pada produk yang akan dijual. Penelitian oleh (Ramos \& Franco, 2015) menyatakan kesadaran merek tercapai melalui upaya komunikasi pemasaran perusahaan terhadap ekuitas merek. Penelitian oleh (Viliaus \& Tobing, 2017) menyatakan bahwa efek positif dari komunikasi pemasaran terpadu pada minat beli akan meningkat manakala ekuitas merek meningkat. Penelitian oleh (Asih, Zulkarnain, \& Alwie, 2018) menyatakan bahwa iklan, personal communication, intruksi, dan desain perusahaan berpengaruh positif signifikan terhadap brand equity. Berdasarkan hasil-hasil penelitian sebelumnya, maka rumusan hipotesis yang dapat diajukan yaitu :

$\mathrm{H}_{2}$ : Marketing communication berpengaruh positif dan signifikan terhadap brand equity pada smartphone Oppo di Kota Denpasar

Salah satu cara yang dapat meningkatkan keinginan konsumen dalam membeli suatu produk adalah melalui WOM. WOM merupakan cara mempromosikan produk secara langsung kepada konsumen berdasarkan pengalaman dari seseorang yang telah dahulu membeli atau menggunakan produk tersebut. Penelitian oleh (Khan et al., 2015) menyatakan bahwa ada dampak positif dari WOM pada minat beli konsumen. Penelitian oleh (Putri et al., 2016) menyatakan bahwa variabel WOM berpengaruh signifikan terhadap variabel minat beli. Penelitian oleh (Prabowo \& Nurhadi, 2016) menyatakan bahwa citra merek, kualitas produk, persepsi harga dan WOM baik secara parsial maupun simultan berpengaruh positif dan signifikan terhadap minat beli. Berdasarkan hasil-hasil penelitian sebelumnya, maka rumusan hipotesis yang dapat diajukan yaitu :

H3: WOM berpengaruh positif dan signifikan terhadap minat beli konsumen pada smartphone Oppo di Kota Denpasar

Strategi komunikasi pemasaran menentukan keberhasilan kegiatan melalui komunikasi yang efektif. Penelitian oleh (Ering \& Pandowo, 2015) menyatakan bahwa iklan yang merupakan salah satu dimensi dari komunikasi pemasaran berdampak negatif terhadap minat beli konsumen. Penelitian oleh (Moniaga et al., 2017) menyatakan bahwa komunikasi pemasaran memberikan pengaruh yang positif dan signifikan terhadap minat beli. Penelitian oleh (Astama \& Sumadhinata, 2014) menyatakan bahwa strategi komunikasi memiliki pengaruh terhadap minat konsumen. Berdasarkan hasil-hasil penelitian sebelumnya, maka rumusan hipotesis yang dapat diajukan yaitu: 
$\mathrm{H}_{4}$ : Marketing communication berpengaruh positif dan signifikan terhadap minat beli konsumen pada smartphone Oppo di Kota Denpasar

Brand equity dapat memberikan pengaruh pada minat beli konsumen pada suatu produk, karena brand equity merupakan cerminan dari kuatnya merek suatu produk yang akan dipasarkan sehingga dapat menarik minat beli dari konsumen. Penelitian oleh (Dewa, 2015) menyatakan bahwa ekuitas merek berpengaruh positif terhadap niat beli. Penelitian oleh (Walangitan et al., 2015) menyatakan bahwa loyalitas merek dan kesadaran merek tidak memiliki pengaruh yang signifikan terhadap niat beli konsumen. Penelitian oleh (Ogbeide \& Omoregbe, 2017) menyatakan bahwa kesadaran merek, loyalitas merek, persepsi kualitas dan asosiasi merek memiliki hubungan positif yang signifikan dengan minat pembelian. Berdasarkan hasil-hasil penelitian sebelumnya, maka rumusan hipotesis yang dapat diajukan yaitu :

$\mathrm{H}_{5}$ : Brand equity berpengaruh positif dan signifikan terhadap minat beli

konsumen pada smartphone Oppo di Kota Denpasar

Ekuitas merek atau brand equity sdapat menjadi nilai tambah pada suatu produk dan jasa. Nilai ini dicerminkan dalam cara konsumen berpikir, merasa dan bertindak terhadap merek, harga, pangsa pasar, dan profitabilitas yang dimiliki perusahaan. Pada penelitian oleh dari (Hamza \& Rahul, 2017) menyatakan bahwa ekuitas merek sepenuhnya dimediasi anteseden tertentu dan sebagian dimediasi dengan orang lain. Penelitian oleh (Walangitan et al., 2015) menyatakan bahwa loyalitas merek dan kesadaran merek yang merupakan dimensi dari brand equity tidak memiliki pengaruh yang signifikan terhadap minat beli konsumen. Penelitian oleh (Ogbeide \& Omoregbe, 2017) menyatakan bahwa kesadaran merek, loyalitas merek, persepsi kualitas dan asosiasi merek memiliki hubungan positif yang signifikan dengan minat pembelian. Kualitas yang dirasakan ditemukan memiliki hubungan yang paling signifikan dengan minat pembelian, diikuti oleh loyalitas merek dan kemudian kesadaran merek sementara asosiasi merek adalah faktor paling signifikan dari minat pembelian. Berdasarkan hasilhasil penelitian sebelumnya, maka rumusan hipotesis yang dapat diajukan yaitu :

$\mathrm{H}_{6}$ : Brand equity dalam memediasi WOM berpengaruh positif dan signifikan terhadap minat beli konsumen pada smartphone Oppo di Kota Denpasar

Brand Equity merupakan serangkaian aset dan kewajiban (liabilities) merek yang terkait dengan sebuah merek, nama dan simbolnya, yang dapat menambah atau mengurangi nilai yang diberikan sebuah produk atau jasa kepada perusahaan dan pelanggan perusahaan tersebut (Harsa \& Syahputra, 2015). Komunikasi pemasaran merupakan interaksi antara produsen dengan calon pelanggan melalui beberapa media terpilih. Penelitian oleh (Moniaga et al., 2017) menyatakan bahwa komunikasi pemasaran memberikan pengaruh yang positif dan signifikan terhadap minat beli produk. Penelitian oleh (Viliaus \& Tobing, 2017) menyatakan bahwa efek positif dari komunikasi pemasaran terpadu pada minat beli akan meningkat manakala ekuitas merek meningkat. Penelitian oleh (Dewantara \& Nurcahya, 2017) menyatakan bahwa ekuitas merek berperan dalam memediasi pengaruh bauran promosi. Berdasarkan hasil-hasil penelitian sebelumnya, maka rumusan hipotesis yang dapat diajukan yaitu : 
$\mathrm{H}_{7}$ : Brand equity dalam memediasi marketing communication berpengaruh positif dan signifikan terhadap minat beli konsumen pada smartphone Oppo di Kota Denpasar

\section{METODE PENELITIAN}

Penelitian ini dilakukan di Kota Denpasar karena merupakan pusat kota sekaligus ibu kota Provinsi Bali, mencerminkan gaya hidup masyarakat Denpasar yang update akan kebutuhan produk-produk terbaru, serta memiliki penduduk dengan usia produktif sebesar 501.909 jiwa (BPS, 2018). Adapun objek yang digunakan dalam penelitian ini yaitu minat beli dari masyarakat di Kota Denpasar yang timbul akibat adanya brand equity, WOM, dan marketing communication dari smartphone Oppo.

Populasi dalam penelitian ini adalah seluruh konsumen kota Denpasar yang belum pernah melakukan pembelian smartphone Oppo namun telah sadar dengan adanya smartphone dengan merek Oppo. Maka dari itu, populasi yang digunakan dalam penelitian ini tidak terbatas, karena jangkauan penelitian yang luas. Dalam penelitian ini, metode penentuan sampel yang digunakan yaitu non probability sampling. Teknik non probability sampling yang dipilih adalah purposive sampling yaitu teknik penentuan sampel dengan pertimbangan tertentu.

Dalam penelitian ini teknik analisis yang digunakan adalah teknik analisis jalur (path analysis).

Sub-struktural 1

Sub-struktural 2

$$
\mathrm{Y}_{1}=\beta_{1} \mathrm{X}_{1}+\beta_{2} \mathrm{X}_{2}+\mathrm{e}_{1}
$$

$$
\mathrm{Y}_{2}=\beta_{3} \mathrm{X}_{1}+\beta_{4} \mathrm{X}_{2}+\beta_{5} \mathrm{Y}_{1}+\mathrm{e}_{2}
$$

Keterangan:

$$
\begin{aligned}
& \mathrm{Y}_{2} \quad=\text { minat beli } \\
& \mathrm{X}_{1} \quad=\text { WOM } \\
& \mathrm{X}_{2} \quad=\text { marketing communication } \\
& \mathrm{Y}_{1} \quad=\text { brand equity } \\
& \beta_{1}, \beta_{2}, \beta_{3,4, \beta_{5}}=\text { koefisien regresi variabel } \\
& \mathrm{e}=\text { error }
\end{aligned}
$$

\section{HASIL DAN PEMBAHASAN}

Berdasarkan data karakteristik responden terlihat bahwa untuk klasifikasi jenis kelamin cenderung didominasi oleh perempuan yakni sebesar 68,8 persen bila dibandingkan dengan persentase responden yang berjenis kelamin laki-laki yang hanya sebesar 31,2 persen. Klasifikasi usia responden mayoritas responden berusia 17-25 tahun yakni sebesar 83,1 persen, kemudian diikuti dengan kelompok usia 26-35 tahun sebesar 5,6 persen, kelompok usia 36-45 tahun sebesar 6,3 persen dan yang terakhir kelompok usia $>45$ tahun sebesar 5 persen. Klasifikasi terakhir yakni klasifikasi pekerjaan atau status, yang dalam penelitian ini mayoritas responden berasal dari mahasiswa/pelajar yakni sebesar 78,8 persen, 
kemudian diikuti dengan pegawai swasta sebesar 10,6 persen, PNS sebesar 5,6 persen, dan yang terakhir wiraswasta sebesar 5 persen.

Penelitian ini menggunakan uji validitas dan uji reliabilitas dalam pengujian instrumen. Uji validitas digunakan untuk menguji apakah instrumen penelitian dapat dikatakan valid apabila mampu mengukur sah atau tidaknya suatu instrument dalam mengungkapkan data dari variabel yang akan diteliti secara tepat. Pengujian reliabilitas atau keandalan instrumen menunjukkan sejauh mana suatu pengukuran dapat konsisten atau stabil dari waktu ke waktu.

Uji validitas bertujuan untuk memeriksa apakah kuesioner sebagai instrumen penelitian sudah tepat untuk mengukur indikator dalam penelitian sehingga dapat dikatakan valid. Hasil uji validitas instrumen penelitian disajikan pada Tabel 5.

Tabel 5.

Hasil Uji Validitas

\begin{tabular}{cccc}
\hline Variabel & Instrumen & Pearson Correlation & Keterangan \\
\hline \multirow{2}{*}{ WOM $\left(\mathrm{X}_{1}\right)$} & $\mathrm{X}_{1.1}$ & 0,911 & Valid \\
& $\mathrm{X}_{1.2}$ & 0,922 & Valid \\
& $\mathrm{X}_{1.3}$ & 0,953 & Valid \\
& $\mathrm{X}_{2.1}$ & 0,806 & Valid \\
Marketing & $\mathrm{X}_{2.2}$ & 0,799 & Valid \\
Communication $\left(\mathrm{X}_{2}\right)$ & $\mathrm{X}_{2.3}$ & 0,926 & Valid \\
& $\mathrm{X}_{24}$ & 0,865 & Valid \\
& $\mathrm{X}_{25}$ & 0,803 & Valid \\
& $\mathrm{Y}_{1.1}$ & 0,756 & Valid \\
Brand Equity $\left(\mathrm{Y}_{1}\right)$ & $\mathrm{Y}_{1.2}$ & 0,832 & Valid \\
& $\mathrm{Y}_{1.3}$ & 0,898 & Valid \\
& $\mathrm{Y}_{14}$ & 0,870 & Valid \\
& $\mathrm{Y}_{2.1}$ & 0,903 & Valid \\
& $\mathrm{Y}_{2.2}$ & 0,881 & Valid \\
Minat beli $\left(\mathrm{Y}_{2}\right)$ & $\mathrm{Y}_{2.3}$ & 0,948 & Valid \\
& $\mathrm{Y}_{2.4}$ & 0,818 & Valid \\
\hline
\end{tabular}

Sumber: Data diolah, 2019

Hasil uji validitas instrumen penelitian yang disajikan dalam Tabel 5 menunjukkan bahwa seluruh indikator pernyataan dalam variabel WOM, marketing communication, brand equity, dan minat beli memiliki pearson correlation lebih besar dari 0,30 sehingga seluruh indikator tersebut telah memenuhi syarat validitas data.

Uji reliabilitas menunjukkan sejauh mana suatu alat pengukur dapat dipercaya atau dapat diandalkan. Apabila suatu alat pengukur dipakai dua kali untuk mengukur gejala yang sama dan hasil pengukuran yang diperoleh relatif konsisten, maka alat pengukur tersebut reliabel. Suatu instrumen dapat dikatakan reliabel apabila nilai Cronbach's Alpha $\geq 0,60$.

Tabel 6. yang menunjukkan bahwa keempat instrumen penelitian yaitu variabel WOM, marketing communication, brand equity, dan minat beli memiliki koefisien Cronbach's Alpha lebih besar dari 0,60 sehingga pernyataan pada kuesioner tersebut reliabel. 
Perhitungan koefisien jalur dilakukan dengan menggunakan SPSS 13, hasil dari pengolahan data untuk persamaan regresi 1 disajikan dalam Tabel 7 sebagai berikut.

Tabel 6.

Hasil Uji Reliabilitas

\begin{tabular}{ccc}
\hline Variabel & Cronbach's Alpha & Keterangan \\
\hline WOM $\left(\mathrm{X}_{1}\right)$ & 0,912 & Reliabel \\
Marketing communication $\left(\mathrm{X}_{2}\right)$ & 0,894 & Reliabel \\
Brand equity $\left(\mathrm{Y}_{1}\right)$ & 0,860 & Reliabel \\
Minat beli $\left(\mathrm{Y}_{2}\right)$ & 0,909 & Reliabel \\
\hline
\end{tabular}

Sumber: Data diolah, 2019

Tabel 7.

Hasil Analisis Jalur Persamaan Regresi 1

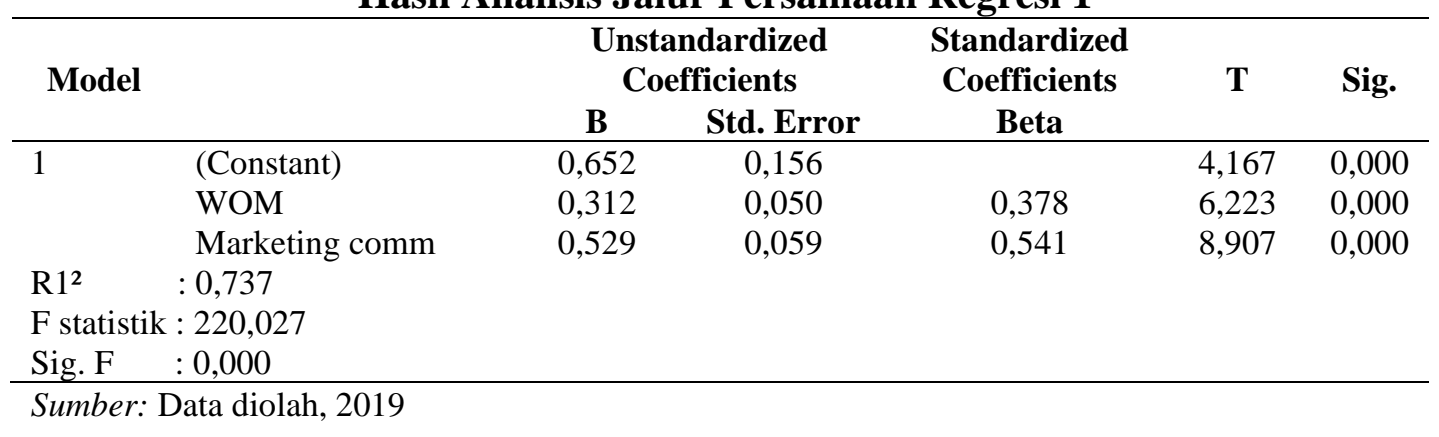

Berdasarkan data yang disajikan pada Tabel 7. maka persamaan strukturalnya dapat disusun sebagai berikut:

$$
\mathrm{Y}_{1}=0,378 \mathrm{X}_{1}+0,541 \mathrm{X}_{2}+\mathrm{e}_{1}
$$

Nilai $\beta_{1}$ adalah sebesar 0,378 memiliki arti WOM berpengaruh positif terhadap brand equity, dengan kata lain jika faktor WOM meningkat maka brand equity konsumen meningkat.

Nilai $\beta_{2}$ adalah sebesar 0,541 memiliki arti marketing communication berpengaruh positif terhadap brand equity, dengan kata lain jika faktor marketing communication meningkat maka brand equity meningkat sebesar 0,541. Hasil pengolahan data untuk persamaan regresi 2 disajikan dalam Tabel 8.

Berdasarkan data yang disajikan pada Tabel 8, maka persamaan strukturalnya dapat disusun sebagai berikut:

$$
\mathrm{Y}_{2}=0,396 \mathrm{X}_{1}+0,191 \mathrm{X}_{2}+0,340 \mathrm{Y}_{1}+\mathrm{e}_{2}
$$

Nilai $\beta_{3}$ adalah sebesar 0,396 memiliki arti WOM berpengaruh positif terhadap minat beli dengan kata lain jika faktor WOM meningkat maka minat beli meningkat. Nilai $\beta_{4}$ adalah sebesar 0,191 memiliki arti marketing communication berpengaruh positif terhadap minat beli, dengan kata lain jika faktor marketing communication meningkat maka minat beli meningkat. Nilai $\beta_{5}$ adalah sebesar 
0,340 memiliki arti brand equity berpengaruh positif terhadap minat beli, dengan kata lain jika faktor brand equity meningkat maka minat beli meningkat.

Tabel 8.

Hasil Analisis Jalur Persamaan Regresi 2

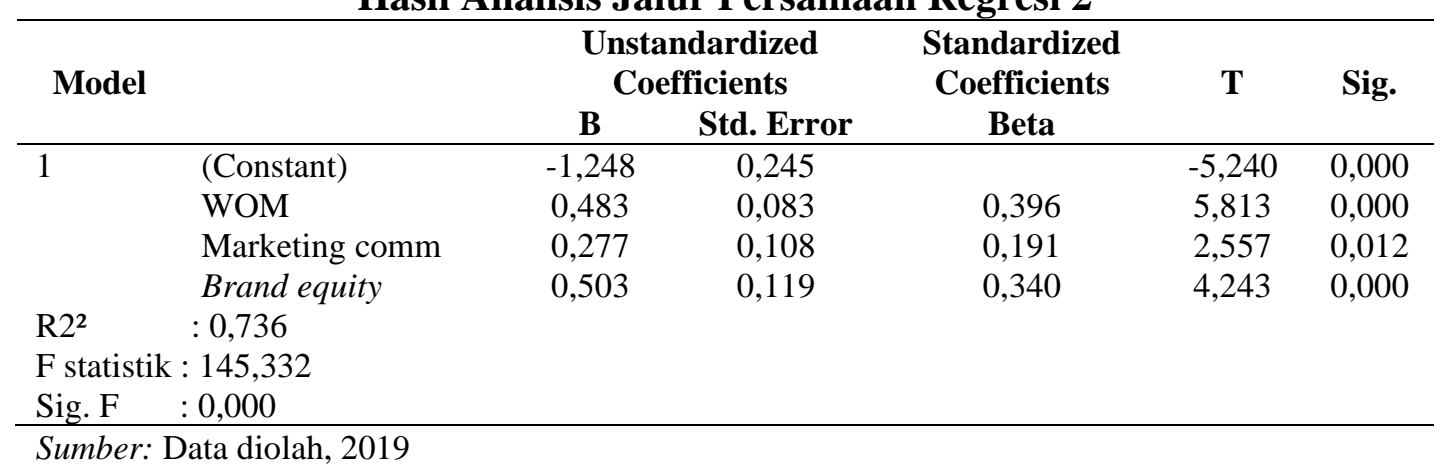

Berdasarkan persamaan regresi 1 dan 2 , diketahui nilai dari $\mathrm{R}_{1}{ }^{2}=0,737$ dan $\mathrm{R}_{2}{ }^{2}=0,736$ maka nilai error untuk masing-masing persamaan dihitung sebagai berikut:

$$
\begin{aligned}
& \mathrm{e}=\sqrt{1-R^{2}} \ldots \ldots \ldots \ldots \ldots \ldots \ldots \ldots \ldots \ldots \ldots \ldots \\
& \mathrm{e}_{1}=\sqrt{1-R 1^{2}}=\sqrt{1-0,737}=0,513 \\
& \mathrm{e}_{2}=\sqrt{1-R 2^{2}}=\sqrt{1-0,736}=0,514
\end{aligned}
$$

Berdasarkan perhitungan di atas, diketahui besarnya pengaruh $\mathrm{e}_{1}=0,513$ dan nilai dari $\mathrm{e}_{2}=0,514$. Dari nilai $\mathrm{e}_{1}$ dan $\mathrm{e}_{2}$ yang telah diketahui maka koefisien determinasi total dapat dihitung sebagai berikut:

$$
\begin{aligned}
\mathrm{R}^{2} \mathrm{~m} & =1-\left(\mathrm{Pe}_{1}\right)^{2}\left(\mathrm{Pe}_{2}\right)^{2} \ldots \ldots \\
& =1-(0,513)^{2}(0,514)^{2} \\
& =1-(0,135)(0,264) \\
& =1-0,036 \\
& =0,964
\end{aligned}
$$

Koefisien determinasi total sebesar 0,964 artinya sebesar 96,4 persen variasi variabel minat beli dipengaruhi oleh variabel brand equity, WOM dan marketing communication, sedangkan sisanya sebesar 3,6 persen dijelaskan oleh faktor lain yang tidak dimasukkan ke dalam model.

Hasil pengujian pada Tabel 8. diperoleh nilai koefisien signifikansi $\mathrm{F} \leq 0,05$ dengan koefisien signifikan $0,000 \leq 0,05$, sehingga $\mathrm{H}_{0}$ ditolak dan $\mathrm{H}_{1}$ diterima. Hasil tersebut menunjukkan bahwa WOM, marketing communication dan brand equity berpengaruh secara signifikan terhadap minat beli. Model persamaan struktural dalam penelitian ini telah memenuhi syarat goodness of fit melalui uji F. Hasil dari analisis diketahui pengaruh WOM terhadap brand equity memiliki koefisien $\beta_{1}=0,378$ dan $p$ value sebesar 0,000 . Nilai koefisien $\beta_{1}>0$ dan $p$ value $\leq$ 0,05 sehingga $\mathrm{H}_{1}$ diterima dan $\mathrm{H}_{0}$ ditolak. Itu berarti WOM berpengaruh positif dan signifikan terhadap brand equity. Hasil dari analisis diketahui pengaruh marketing communication terhadap brand equity memiliki koefisien $\beta_{2}=0,541$ dan $p$ value sebesar 0,000 . Nilai koefisien $\beta_{2}>0$ dan $p$ value $\leq 0,05$ sehingga $\mathrm{H}_{2}$ diterima dan $\mathrm{H}_{0}$ ditolak. Itu berarti marketing communication berpengaruh positif 
dan signifikan terhadap brand equity. Hasil dari analisis diketahui pengaruh WOM terhadap minat beli memiliki koefisien $\beta_{3}=0,396$ dan $p$ value sebesar 0,000 . Nilai koefisien $\beta_{3}>0$ dan $p$ value $\leq 0,05$ sehingga $\mathrm{H}_{3}$ diterima dan $\mathrm{H}_{0}$ ditolak. Itu berarti WOM berpengaruh positif dan signifikan terhadap minat beli.

Hasil pada Tabel 8. diketahui pengaruh marketing communication terhadap minat beli memiliki koefisien $\beta_{4}=0,191$ dan $p$ value sebesar 0,012 . Nilai koefisien $\beta_{4}>0$ dan $p$ value $\leq 0,05$ sehingga $\mathrm{H}_{4}$ diterima dan $\mathrm{H}_{0}$ ditolak. Itu berarti marketing communication berpengaruh positif dan signifikan terhadap minat beli.

Hasil pada Tabel 8. diketahui pengaruh brand equity terhadap minat beli memiliki koefisien $\beta_{5}=0,340$ dan $p$ value sebesar 0,000 . Nilai koefisien $\beta_{5}>0$ dan $p$ value $\leq 0,05$ sehingga $\mathrm{H}_{5}$ diterima dan $\mathrm{H}_{0}$ ditolak. Itu berarti brand equity berpengaruh positif dan signifikan terhadap minat beli.

Perhitungan pengaruh antar variabel ditunjukkan pada Tabel 9 berikut

Tabel 9.

Pengaruh Langsung, Pengaruh Tidak Langsung dan Pengaruh Total WOM (X1), Marketing Communication ( $\left.\mathrm{X}_{2}\right)$, Brand Equity ( $\left.\mathrm{Y}_{1}\right)$, dan Minat Beli ( $\left.\mathrm{Y}_{2}\right)$

\begin{tabular}{cccc}
\hline $\begin{array}{c}\text { Pengaruh } \\
\text { Variabel }\end{array}$ & $\begin{array}{c}\text { Pengaruh } \\
\text { Langsung }\end{array}$ & $\begin{array}{c}\text { Pengaruh Tidak langsung Melalui } \\
\text { Brand Equity }\end{array}$ & $\begin{array}{c}\text { Pengaruh } \\
\text { Total }\end{array}$ \\
\hline $\mathrm{X}_{1} \rightarrow \mathrm{Y}_{1}$ & 0,378 & - & 0,378 \\
$\mathrm{X}_{2} \rightarrow \mathrm{Y}_{1}$ & 0,541 & - & 0,541 \\
$\mathrm{X}_{1} \rightarrow \mathrm{Y}_{2}$ & 0,396 & 0,129 & 0,525 \\
$\mathrm{X}_{2} \rightarrow \mathrm{Y}_{2}$ & 0,191 & 0,184 & 0,375 \\
$\mathrm{Y}_{1} \rightarrow \mathrm{Y}_{2}$ & 0,340 & - & 0,340 \\
\hline
\end{tabular}

Sumber: Data diolah, 2019

Tabel 9. menunjukkan bahwa WOM berpengaruh langsung terhadap minat beli sebesar 39,6 persen, dengan dimediasi brand equity maka didapatkan pengaruh tidak langsung sebesar 12,9 persen, dan pengaruh total sebesar 52,5 persen. Hasil tersebut menunjukkan bahwa brand equity memediasi pengaruh WOM terhadap minat beli secara parsial.

Tabel 9. juga menunjukkan pengaruh langsung variabel marketing communication terhadap minat beli sebesar 19,1 persen, serta pengaruh tidak langsung yang dimediasi brand equity memperoleh nilai beta sebesar 18,4 persen. Hal tersebut menunjukkan bahwa brand equity memediasi pengaruh marketing communication terhadap minat beli dengan pengaruh total sebesar 37,5 persen. Hasil tersebut menunjukkan bahwa brand equity memediasi secara parsial pengaruh marketing communication terhadap minat beli.

Uji normalitas bertujuan untuk mengetahui apakah residual dari model regresi yang dibuat berdistribusi normal atau tidak. Untuk menguji apakah data yang digunakan normal atau tidak dapat dilakukan dengan menggunakan uji Kolmogorov Smirnov. Apabila koesifien Asymp. Sig. (2-tailed) lebih besar dari 0,05 maka data tersebut dikatakan berdistribusi normal.

Tabel 10. menunjukkan nilai Kolmogorov Smirnov $(K-S)$ sebesar 1,016 sedangkan nilai Asymp.Sig. (2-tailed) sebesar 0,254. Hasil tersebut mengindikasikan bahwa model persamaaan regresi tersebut berdistribusi normal 
karena nilai Asymp. Sig. (2-tailed) sebesar 0,254 dimana lebih besar dari nilai alpha yaitu 0,05 .

Tabel 10.

Hasil Uji Normalitas Persamaan Regresi 1

\begin{tabular}{cc}
\hline & Unstandardized Residual \\
\hline $\mathrm{N}$ & 160 \\
Kolmogorov Smirnov & 1.016 \\
Asymp. Sig. (2-tailed) & 0.254 \\
\hline
\end{tabular}

Sumber: Data diolah, 2019

Tabel 11.

Hasil Uji Normalitas Persamaan Regresi 2

\begin{tabular}{cc}
\hline & Unstandardized Residual \\
\hline $\mathrm{N}$ & 160 \\
Kolmogorov Smirnov & 1.208 \\
Asymp. Sig. (2-tailed) & 0.108 \\
\hline Sumber: Data diolah, 2019
\end{tabular}

Tabel 11. menunjukkan nilai Kolmogorov Smirnov $(K-S)$ sebesar 1,208 sedangkan nilai Asymp.Sig. (2-tailed) sebesar 0,108. Hasil tersebut mengindikasikan bahwa model persamaaan regresi tersebut berdistribusi normal karena nilai Asymp. Sig. (2-tailed) sebesar 0,108 dimana lebih besar dari nilai alpha yaitu 0,05 .

Uji multikolinieritas bertujuan untuk menguji apakah pada model regresi ditemukan adanya korelasi antar variabel bebas. Adanya multikolinieritas dapat dilihat dari nilai tolerance atau variance inflaction factor (VIF). Jika nilai tolerance lebih dari $10 \%$ atau VIF kurang dari 10, maka dapat dikatakan tidak ada multikolinieritas.

Tabel 12.

Hasil Uji Multikolinieritas Persamaan Regresi 1

\begin{tabular}{lcc}
\hline \multicolumn{1}{c}{ Variabel } & Tolerance & VIF \\
\hline WOM & 0,454 & 2,201 \\
Marketing communication & 0,454 & 2,201 \\
\hline
\end{tabular}

Sumber: Data diolah, 2019

Tabel 12. menunjukkan nilai tolerance dan VIF dari variabel WOM dan marketing communication. Nilai tersebut menunjukkan bahwa nilai tolerance untuk setiap variabel lebih besar dari 10 persen dan nilai VIF lebih kecil dari 10 yang berarti model persamaan regresi 1 bebas dari multikolinieritas.

Tabel 13.

Hasil Uji Multikolinieritas Persamaan Regresi 2

\begin{tabular}{lcc}
\hline \multicolumn{1}{c}{ Variabel } & Tolerance & VIF \\
\hline WOM & 0,364 & 2,744 \\
Marketing communication & 0,302 & 3,313 \\
Brand equity & 0,263 & 3,803 \\
\hline Sumber: Data diolah, 2019 & &
\end{tabular}

Sumber: Data diolah, 2019 
Tabel 13. menunjukkan nilai tolerance dan VIF dari variabel WOM, marketing communication dan brand equity. Nilai tersebut menunjukkan bahwa nilai tolerance untuk setiap variabel lebih besar dari 10 persen dan nilai VIF lebih kecil dari 10 yang berarti model persamaan regresi 2 bebas dari multikolinieritas.

Uji Heteroskedastisitas bertujuan untuk mengetahui apakah dalam model regresi terjadi ketidaksamaan varians dari residual satu pengamatan ke pengamatan yang lain yang dilakukan dengan uji Glejser. Jika tidak ada satu pun variabel bebas yang berpengaruh signifikan terhadap nilai absolut residual atau nilai signifikansinya di atas atau 0,05 maka tidak mengandung gejala heteroskedastisitas.

Tabel 14.

Hasil Uji Heteroskedastisitas Persamaan Regresi 1

\begin{tabular}{|c|c|c|c|c|c|c|}
\hline \multirow[t]{2}{*}{ Model } & & \multicolumn{2}{|c|}{$\begin{array}{l}\text { Unstandardized } \\
\text { Coefficients }\end{array}$} & \multirow{2}{*}{$\begin{array}{c}\text { Standardized } \\
\text { Coefficients } \\
\text { Beta } \\
\end{array}$} & \multirow[t]{2}{*}{$\mathbf{T}$} & \multirow[t]{2}{*}{ Sig. } \\
\hline & & B & Std. Error & & & \\
\hline \multirow[t]{5}{*}{1} & (Constant) & 0,363 & 0,102 & & 3,560 & 0,000 \\
\hline & WOM & 0,025 & 0,033 & 0,091 & 0,770 & 0,442 \\
\hline & Marketing & $-0,053$ & 0,039 & $-0,161$ & $-1,369$ & 0,173 \\
\hline & communication & & & & & \\
\hline & Dependent Variabel : & Absres 1 & & & & \\
\hline
\end{tabular}

Sumber: Data diolah, 2019

Tabel 14. menunjukkan nilai signifikansi dari variabel WOM sebesar 0,442 lebih besar dari 0,05 dan variabel marketing communication sebesar 0,173 lebih besar dari 0,05 yang berarti tidak terdapat pengaruh antara variabel bebas terhadap absolut residual. Dengan demikian, model yang dibuat tidak mengandung gejala heteroskedastisitas.

Tabel 15.

Hasil Uji Heteroskedastisitas Persamaan Regresi 2

\begin{tabular}{|c|c|c|c|c|c|c|}
\hline \multirow[t]{2}{*}{ Model } & & \multicolumn{2}{|c|}{$\begin{array}{l}\text { Unstandardized } \\
\text { Coefficients }\end{array}$} & \multirow{2}{*}{$\begin{array}{c}\text { Standardized } \\
\text { Coefficients } \\
\text { Beta } \\
\end{array}$} & \multirow[t]{2}{*}{$\mathbf{T}$} & \multirow[t]{2}{*}{ Sig. } \\
\hline & & B & Std. Error & & & \\
\hline \multirow[t]{4}{*}{1} & (Constant) & 1,049 & 0,152 & & 6,898 & 0,000 \\
\hline & WOM & 0,016 & 0,052 & 0,040 & 0,318 & 0,751 \\
\hline & Marketing & $-0,061$ & 0,067 & $-0,125$ & $-0,908$ & 0,365 \\
\hline & $\begin{array}{l}\text { communication } \\
\text { Brand equity }\end{array}$ & $-0,130$ & 0,074 & $-0,260$ & $-1,766$ & 0,079 \\
\hline
\end{tabular}

Sumber: Data diolah, 2019

Tabel 15. menunjukkan nilai signifikansi dari variabel WOM, marketing communication dan brand equity masing-masing sebesar 0,$751 ; 0,365 ; 0,079$. Nilai-nilai tersebut lebih besar dari 0,05 yang berarti tidak terdapat pengaruh antara variabel bebas terhadap absolut residual. Dengan demikian, model yang dibuat tidak mengandung gejala heteroskedastisitas. 
Uji Sobel merupakan teknik analisis untuk menguji signifikansi dan pengaruh tidak langsung antara variabel independen dengan variabel dependen yang dimediasi oleh variabel mediator. Uji Sobel dihitung dengan menggunakan aplikasi Microsoft Excel 2010. Nilai koefisien z jika lebih besar dari 1,96, maka variabel brand equity dalam penelitian ini dinilai secara signifikan mampu memediasi pengaruh WOM dan marketing communication terhadap minat beli.

Peran Brand Equity Memediasi WOM dengan Minat Beli pada Uji Sobel dihitung dengan persamaan sebagai berikut:

$$
\mathrm{Z}=\frac{\mathrm{ab}}{\sqrt{\mathrm{b}^{2} \mathrm{Sa}^{2}+\mathrm{a}^{2} \mathrm{Sb}^{2}+\mathrm{Sa}^{2} \mathrm{Sb}^{2}}}
$$

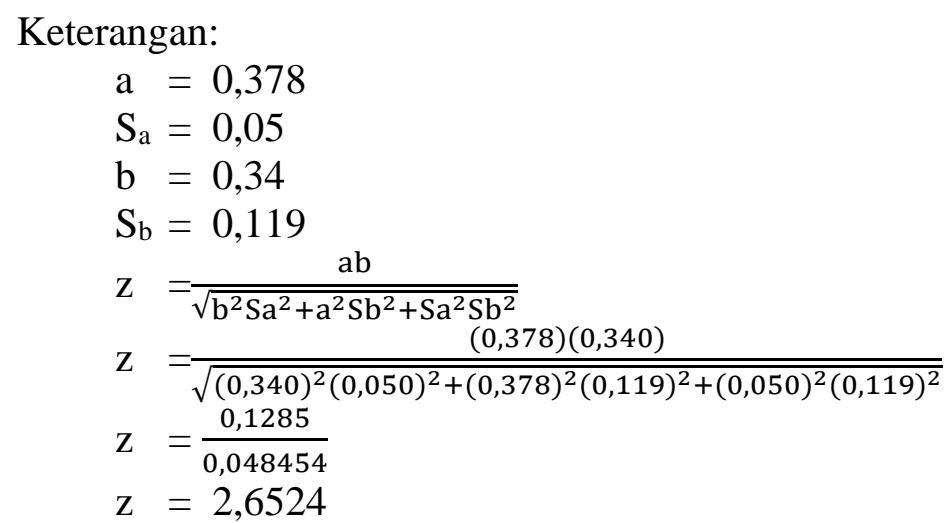

Hasil Uji Sobel yang telah dihitung menunjukkan bahwa nilai koefisien z adalah 2,6524> 1,96 dengan tingkat signifikansi $0,0080<0,05$, sehingga $\mathrm{H}_{0}$ ditolak dan $\mathrm{H}_{1}$ diterima. Hasil tersebut mengartikan bahwa brand equity sebagai variabel mediasi dinilai secara positif dan signifikan mampu memediasi pengaruh WOM terhadap minat beli.

Peran Brand Equity Memediasi Marketing Communication dengan Minat Beli pada Uji Sobel dihitung dengan persamaan sebagai berikut:

Keterangan:

$$
\mathrm{z}=\frac{\mathrm{ab}}{\sqrt{\mathrm{b}^{2} \mathrm{Sa}^{2}+\mathrm{a}^{2} \mathrm{Sb}^{2}+\mathrm{Sa}^{2} \mathrm{Sb}^{2}}}
$$

$$
\begin{aligned}
& \mathrm{a}=0,541 \\
& \mathrm{~S}_{\mathrm{a}}=0,059 \\
& \mathrm{~b}=0,340 \\
& \mathrm{~S}_{\mathrm{b}}=0,119 \\
& \mathrm{z}=\frac{\mathrm{ab}}{\sqrt{\mathrm{b}^{2} \mathrm{Sa}^{2}+\mathrm{a}^{2} \mathrm{Sb}^{2}+\mathrm{Sa}^{2} \mathrm{Sb}^{2}}} \\
& \mathrm{z}=\frac{(0,541)(0,340)}{\sqrt{(0,340)^{2}(0,059)^{2}+(0,541)^{2}(0,119)^{2}+(0,059)^{2}(0,119)^{2}}} \\
& \mathrm{z}=\frac{0,1839}{0.067082} \\
& \mathrm{z}=2,7131
\end{aligned}
$$

Hasil Uji Sobel yang telah dihitung menunjukkan bahwa nilai koefisien $\mathrm{z}$ adalah 2,7131> 1,96 dengan tingkat signifikansi $0,0067<0,05$, sehingga $\mathrm{H}_{0}$ ditolak dan $\mathrm{H}_{1}$ diterima. Hasil tersebut mengartikan bahwa brand equity sebagai variabel mediasi dinilai secara positif dan signifikan mampu memediasi pengaruh marketing communication terhadap minat beli. 
Pengaruh antara WOM terhadap brand equity dalam penelitian ini menunjukkan bahwa WOM berpengaruh positif dan signifikan terhadap brand equity. Ini berarti, semakin baik penyampaian WOM maka akan meningkatkan brand equity produk smartphone Oppo. Hasil rangkuman penilaian responden yang disajikan dalam deskripsi variabel penelitian menunjukkan bahwa persepsi responden terhadap penyampaian WOM pada smartphone produk Oppo di Kota Denpasar berada dalam kategori baik. Responden merasa penyampaian informasi mengenai smartphone produk Oppo mengandung unsur positif.

Hasil penelitian ini sesuai dengan rumusan hipotesis yang menyatakan bahwa WOM berpengaruh positif dan signifikan terhadap brand equity pada smartphone Oppo di Kota Denpasar. Hasil penelitian ini mendukung penelitian yang dilakukan oleh (Sulistyowati et al., 2014) yang menyatakan bahwa WOM berpengaruh positif terhadap ekuitas merek. Menurut penelitian oleh (Sulistyowati et al., 2014), brand equity dapat terbentuk karena adanya WOM yang positif. Hasil penelitian ini bertentangan dengan penelitian (Malino, 2015). Pada hasil penelitian (Malino, 2015) menyatakan bahwa WOM terhadap dimensi brand equity berpengaruh negatif signifikan, dimana perusahaan juga harus mempertimbangkan keinginan konsumen dalam membaca review produk langsung melalui website resmi perusahaan.

Pengaruh antara marketing communication terhadap brand equity dalam penelitian ini menunjukkan bahwa marketing communication berpengaruh positif dan signifikan terhadap brand equity. Ini berarti, semakin baik penyampaian marketing communicationdari perusahaan, maka akan semakin meningkat brand equity pada smartphone Oppo di Kota Denpasar. Hasil rangkuman penilaian responden yang disajikan dalam deskripsi variabel penelitian menunjukkan bahwa persepsi responden terhadap marketing communication yang disampaikan oleh perusahaan Oppo berada dalam kategori baik. Responden mengakui produk smartphone Oppo mempromosikan produknya dengan baik sehingga dapat mendorong minat konsumen untuk membeli produknya.

Hasil penelitian ini sesuai dengan rumusan hipotesis yang menyatakan bahwa marketing communication berpengaruh positif dan signifikan terhadap brand equity pada konsumen produk Oppo di Kota Denpasar. Hasil penelitian ini mendukung penelitian yang dilakukan oleh (Asih et al., 2018) yang menyatakan bahwa iklan, personal communication, intruksi, dan desain perusahaan berpengaruh positif signifikan terhadap brand equity. Hasil juga mendukung penelitian oleh (Ramos \& Franco, 2015) yang menyatakan kesadaran merek tercapai melalui upaya komunikasi pemasaran perusahaan terhadap ekuitas merek.

Pengaruh antara WOM terhadap minat beli dalam penelitian ini menunjukkan bahwa WOM berpengaruh positif dan signifikan terhadap minat beli. Ini berarti, semakin baik penyampaian WOM mengenai produk Oppo, maka akan semakin meningkat minat belipada konsumen produk Oppo di Kota Denpasar. Hasil rangkuman penilaian responden yang disajikan dalam deskripsi variabel penelitian menunjukkan bahwa persepsi responden terhadap WOM yang dimiliki oleh produk Oppo berada dalam kategori baik. Responden menilai penyampaian WOM yang positif membuat responden tertarik untuk mencari tahu mengenai produk Oppo. 
Hasil penelitian ini sesuai dengan rumusan hipotesis yang menyatakan bahwa WOM berpengaruh positif dan signifikan terhadap minat beli konsumen pada produk Oppo di Kota Denpasar. Hasil penelitian ini mendukung penelitian yang dilakukan oleh (Prabowo \& Nurhadi, 2016) menyatakan bahwa WOM baik secara parsial maupun simultan berpengaruh positif dan signifikan terhadap minat beli. Hasil juga mendukung penelitian oleh (Putri et al., 2016) menyatakan bahwa variabel WOM berpengaruh signifikan terhadap variabel minat beli. Penelitian oleh (Putri et al., 2016) menyatakan bahwa WOM yang berasal dari keluarga, teman dekat, dan rekan kerja dan beberapa karakteristik pemimpin opini akan menciptakan minat beli konsumen sehingga konsumen yang telah mendapat rekomendasi dari orang disekitarnya akan tertarik untuk mencari informasi lebih lanjut tentang produk terkait.

Pengaruh antara marketing communication terhadap minat beli dalam penelitian ini menunjukkan bahwa marketing communication berpengaruh positif dan signifikan terhadap minat beli.Ini berarti, semakin baik penyampaian marketing communication yang dilakukan oleh perusahaan produk Oppo, maka dapat meningkatkan minat beli konsumen di Kota Denpasar. Hasil rangkuman penilaian responden yang disajikan dalam deskripsi variabel penelitian menunjukkan bahwa persepsi responden terhadap marketing communication produk Oppo di Kota Denpasar berada dalam kategori baik. Responden merasa bahwa pemberian insentif serta citra baik dari produk Oppo meningkatkan minat beli konsumen.

Hasil penelitian ini sesuai dengan rumusan hipotesis yang menyatakan bahwa marketing communication berpengaruh positif dan signifikan terhadap minat beli konsumen terhadap produk Oppo di Kota Denpasar. Hasil penelitian ini mendukung penelitian yang dilakukan oleh (Moniaga et al., 2017) menyatakan bahwa komunikasi pemasaran memberikan pengaruh yang positif dan signifikan terhadap minat beli. Melakukan penjualan produk yang dapat memberikan pelayanan dan menciptakan pendekatan dengan masyarakat membuat timbulnya minat beli seseorang. Dari hasil tersebut menunjukkan bahwa semakin tinggi pengaruh komunikasi pemasaran maka semakin tinggi tingkat minat beli produk. Hasil ini bertentangan dengan penelitian dari (Ering \& Pandowo, 2015) yang menyatakan bahwa iklan yang merupakan salah satu dimensi dari komunikasi pemasaran berdampak negatif terhadap minat beli konsumen, dan indikator paling dominan adalah personal selling.

Pengaruh antara brand equity terhadap minat beli dalam penelitian ini menunjukkan bahwa brand equity berpengaruh positif dan signifikan terhadap minat beli.Ini berarti, semakin baik brand equitymaka minat beli pada konsumen produk Oppo di Kota Denpasarakan semakin meningkat. Hasil rangkuman penilaian responden yang disajikan dalam deskripsi variabel penelitian menunjukkan bahwa persepsi responden terhadapnilai produk Oppo di Kota Denpasar berada dalam kategori baik.Responden merasa bahwa produk Oppo memiliki kualitas yang baik sehingga membuat minat beli konsumen meningkat.

Hasil penelitian ini sesuai dengan rumusan hipotesis yang menyatakan bahwa brand equity berpengaruh positif dan signifikan terhadap minat beli.Hasil penelitian ini mendukung penelitian yang dilakukan oleh (Ogbeide \& Omoregbe, 
2017) menyatakan bahwa kesadaran merek, loyalitas merek, persepsi kualitas dan asosiasi merek memiliki hubungan positif yang signifikan dengan minat pembelian. Penelitian oleh (Ogbeide \& Omoregbe, 2017) menyatakan bahwa ketika sebuah produk memiliki nama merek terkenal, hal tersebut dapat memenangkan preferensi konsumen dan meningkatkannya minat beli konsumen. Pada hasil penelitian yang dilakukan oleh (Walangitan et al., 2015) menyatakan bahwa loyalitas merek dan kesadaran merek tidak memiliki pengaruh yang signifikan terhadap minat beli konsumen. Kondisi ini terjadi karena terdapat produk lain yang sudah populer terlebih dahulu sehingga loyalitas merek tidak dapat tercapai.

Hasil uji pengaruh langsung variabel WOM terhadap minat beli menunjukkan bahwa brand equity memediasi pengaruh WOM terhadap minat beli secara parsial. Hasil uji sobel juga menunjukkan bahwa brand equity mampu memediasi pengaruh WOM terhadap minat beli secara positif dan signifikan. Brand equity mampu menjadi perantara bagi WOM untuk menimbulkan minat beli. Kualitas yang baik serta kesadaran konsumen mengenai keberadaan produk Oppo meningkatkan informasi positif terhadap produk tersebut yang dirasakan oleh konsumen dan dapat mendorong konsumen lainnya untuk melakukan pembelian produk Oppo.

Hasil penelitian ini sesuai dengan rumusan hipotesis yang menyatakan bahwa brand equity secara signifikan berperan dalam memediasi pengaruh WOM terhadap minat beli. Hasil penelitian ini sejalan dengan penelitian oleh (Ogbeide \& Omoregbe, 2017) menyatakan bahwa kesadaran merek, loyalitas merek, persepsi kualitas dan asosiasi merek memiliki hubungan positif yang signifikan dengan minat pembelian. Kualitas yang dirasakan ditemukan memiliki hubungan yang paling signifikan dengan minat pembelian, karena kualitas yang baik akan membuat konsumen puas serta dapat meningkatkan minat beli dari konsumen lainnya. Penelitian lain yang dilakukan oleh (Hamza \& Rahul, 2017) menyatakan bahwa ekuitas merek sepenuhnya dimediasi anteseden tertentu dan sebagian dimediasi dengan orang lain. Seluruh elemen dari brand equity dapat mempengaruhi minat beli melalui penyampaian informasi yang positif, namun dibutuhkan perhatian khusus agar penyampaian tersebut dapat berkenan di benak konsumen.

Hasil uji pengaruh langsung variabel marketing communication terhadap minat beli menunjukkan bahwa brand equity memediasi pengaruh marketing communication terhadap minat beli secara parsial. Hasil uji sobel menunjukkan bahwa brand equity secara positif dan signifikan memediasi pengaruh marketing communication terhadap minat beli. Brand equity mampu menjadi perantara variabel marketing communication untuk menciptakan minat beli. Insentif berupa garansi selama 1 bulan yang diberikan pada produk Oppo membuat konsumen merasa puas dan yakin untuk memilih Oppo sebagai salah satu pilihan smartphone yang akan dibeli dalam waktu dekat.

Hasil penelitian ini sesuai dengan rumusan hipotesis yang menyatakan bahwa brand equity secara signifikan berperan dalam memediasi pengaruh marketing communication terhadap minat beli. Hasil penelitian ini sejalan dengan penelitian oleh (Moniaga et al., 2017) menyatakan bahwa komunikasi pemasaran 
memberikan pengaruh yang positif dan signifikan terhadap minat beli produk. Beberapa konsumen akan memandang citra baik yang dimiliki oleh produk Oppo untuk mempertimbangkan tindakan dalam melakukan pembelian. Penelitian yang dilakukan oleh (Dewantara \& Nurcahya, 2017) menyatakan bahwa ekuitas merek berperan dalam memediasi pengaruh bauran promosi. Ekuitas merek menjadi faktor penting dalam melakukan pembelian oleh pengguna smartphone. Bauran promosi memiliki pengaruh positif dan signifikan terhadap ekuitas merek, artinya ketika strategi promosi dilakukan secara optimal maka kekuatan ekuitas merek dari produk tersebut akan meningkat.

Implikasi dari hasil penelitian ini mencakup dua hal yaitu, implikasi teoritis dan implikasi praktis. Implikasi teoritis berhubungan dengan kontribusinya bagi perkembangan teori-teori mengenai variabel WOM, marketing communication, brand equity, dan minat beli. Sedangkan implikasi praktis berkaitan dengan kontribusi penelitian kepada pihak perusahaan smartphone Oppo sebagai bahan pertimbangan dalam merumuskan kebijakan pemasaran yang berhubungan dengan WOM serta marketing communication untuk menciptakan brand equity yang tinggi sehingga akan berdampak pada minat beli.

Hasil penelitian inidapat memberikan kontribusi empiris tentang hubungan antara variabel WOM, marketing communication, brand equity, dan minat beli pada pengembangan ilmu pemasaran. Pengolahan data menggunakan teknik analisis jalur (path analysis) untuk memperkirakan hubungan kausalitas antara variabel-variabel yang telah ditetapkan sebelumnya berdasarkan teori, uji asumsi klasik juga digunakan dalam pengolahan data dalam penelitian ini dengan tujuan untuk memastikan hasil yang diperoleh telah memenuhi asumsi dasar di dalam analisis regresi. Penelitian ini juga menggunakan Uji Sobel untuk menguji kekuatan pengaruh tidak langsung variabel WOM dan marketing communication terhadap variabel minat beli melalui variabel brand equity. Hasil penelitian ini diharapkan dapat digunakan untuk memperkaya referensi dan ilmu pengetahuan yang berkaitan dengan variabel terkait.

Hasil penelitian ini dapat menjadi referensi bagi perusahaan smartphone Oppo dalam memanfaatkan aspek WOM dan menciptakan brand equity yang baik bagi konsumen sehingga mampu meningkatkan citra produk pada benak konsumen yang pada akhirnya menciptakan minat beli. Pernyataan pada variabel WOM menunjukkan bahwa konsumen menilai produk smartphone Oppo memiliki citra positif sehingga menghasilkan informasi positif yang dapat meningkatkan minat konsumen dalam membeli produk Oppo. Selain itu pada variabel marketing communication, konsumen menilai bahwa insentif serta penyampaian promosi yang menarik melalui media terpilih dapat mendorong konsumen untuk menggunakan Oppo. Pada variabel brand equity, konsumen secara keseluruhan merasa sadar mengenai keberadaan smartphone dengan merek Oppo dan yakin produk Oppo memiliki kualitas yang baik sehingga membuat konsumen ingin mencari lebih banyak informasi mengenai smartphone Oppo. Hasil penelitian sesuai dengan pernyataan-peryataan pada kuesioner menunjukkan bahwa penilaian konsumen terhadap produk smartphone Oppo termasuk dalam kategori baik. 


\section{SIMPULAN}

WOM berpengaruh positif dan signifikan terhadap brand equity. Hasil ini berarti bahwa semakin positif penyampaian WOM mengenai produk Oppo, maka akan semakin meningkat brand equity produk Oppo di Kota Denpasar. Marketing communication berpengaruh positif dan signifikan terhadap brand equity. Hasil ini berarti bahwa apabila semakin positif penyampaian marketing communication mengenai produk maka akan semakin meningkat brand equity produk Oppo di Kota Denpasar. WOM berpengaruh positif dan signifikan terhadap minat beli. Hasil ini berarti bahwa semakin baik penyampaian WOM mengenai produk Oppo, maka akan meningkatkan minat beli konsumen pada produk smartphone Oppo di Kota Denpasar. Marketing communication berpengaruh positif dan signifikan terhadap minat beli. Hasil ini berarti bahwa semakin baik penyampaian marketing communication yang disampaikan pada konsumen terhadap produk, maka akan meningkatkan minat beli konsumen pada produk smartphone Oppo di Kota Denpasar. Brand equity berpengaruh positif dan signifikan terhadap minat beli. Hasil ini berarti bahwa semakin tinggi brand equity produk maka akan meningkatkan minat beli pada produk smartphone Oppo di Kota Denpasar. Brand equity secara positif dan signifikan berperan dalam memediasi pengaruh WOM terhadap minat beli. Hasil analisis yang diperoleh dari kedua teknik analisis menunjukkan bahwa secara positif dan signifikan brand equity mampu memediasi pengaruh WOM terhadap minat beli produk smartphone Oppo di Kota Denpasar. Brand equity secara positif dan signifikan berperan dalam memediasi pengaruh marketing communication terhadap minat beli. Hasil analisis yang diperoleh dari kedua teknik analisis menunjukkan bahwa secara positif dan signifikan brand equity mampu memediasi pengaruh marketing communication terhadap minat beli produk smartphone Oppo di Kota Denpasar.

Jawaban responden mengenai mendapat ajakan melalui teman untuk menggunakan smartphone Oppo yang merupakan variabel dari WOM mendapatkan skor terendah, maka saran bagi perusahaan untuk dapat meningkatkan kualitas produknya, sehingga semakin banyak konsumen yang merasa puas dan merekomendasikan produk Oppo kepada orang-orang di sekelilingnya. Jawaban responden mengenai menjadikan Oppo sebagai salah satu pilihan ketika akan membeli smartphone yang merupakan variabel dari brand equity mendapatkan skor terendah, maka saran bagi perusahaan agar dapat meningkatkan promosinya, baik dari media cetak maupun media lainnya, agar dapat lebih meyakinkan konsumen untuk membeli produk Oppo. Jawaban responden mengenai Oppo menawarkan produk secara langsung yang merupakan variabel dari marketing communication memperoleh skor terendah, maka saran bagi perusahaan sebaiknya meningkatkan intensitas untuk bertemu dengan konsumen dan meningkatkan komunikasi pemasarannya sehingga dapat meningkatkan minat beli konsumen pada produk Oppo.

\section{REFERENSI}

Aditya, K. Y., \& Wardana, I. M. (2017). Peran Brand Equity Dalam Memediasi Pengaruh Word Of Mouth Terhadap Minat Beli. E-Jurnal Manajemen Unud, 
6(2), 830-856.

Armelini, G. (2011). The Effect of Word of Mouth in Customer Equity and Brand Equity. Chinese Business Review, 10(03), 205-216. https://doi.org/10.17265/1537-1506/2011.03.005

Asih, A. T., Zulkarnain, \& Alwie, A. F. (2018). Pengaruh Komunikasi Pemasaran Terpadu Terhadap Ekuitas Merek Dan Keputusan Pembelian (Studi Pada Hotel Swiss-Belinn Ska Pekanbaru). Jurnal Tepak Manajemen Bisnis, X.

Astama, L. P., \& Sumadhinata, Y. E. (2014). Analisis Pengaruh Strategi Komunikasi Terhadap Minat Beli Konsumen Pada Shooters Pool Tables. 222-239.

Aydin, G., \& Ulengin, B. (2015). Effect of Consumer Brand Equity on Purchase Intention: Considering Socioeconomic Status and Gender as Moderating Effects. Journal of Euromarketing, 24, 107-119. https://doi.org/10.9768/0024.02.107

Badan Pusat Statistik. (2018). Penduduk Usia 15 Tahun ke Atas yang Bekerja di Provinsi Bali Menurut Kabupaten/Kota, 2007-2017. Agustus.BPS Provinsi Bali.Denpasar.

Bougenvile, A., \& Ruswanti, E. (2017). Brand Equity on Purchase Intention Consumers' Willingness to Pay Premium Price Juice. IOSR Journal of Economics and Finance, 8(01), 12-18. https://doi.org/10.9790/59330801031218

Budiarti, A., Surachman, Hawidjojo, D., \& Djumahir. (2013). Brand Equity and Customer Satisfaction as the Mediation of Advertisement influence and the Service Quality to Loyalty the Passengers of International Flight at Garuda Indonesia Airlines. IOSR Journal of Business and Management, 9(2), 1-15. https://doi.org/10.9790/487x-0920115

Dewa, C. B. (2015). Pengaruh Country Of Origin Produk Televisi LG Terhadap Niat Beli Konsumen Dengan Ekuitas Merek Sebagai Variabel Pemediasi. Jurnal Bianglala Informatika, 3(1), 74-82.

Dewantara, A. A., \& Nurcahya, I. K. (2017). Peran Ekuitas Merek Dalam Memediasi Bauran Promosi Dengan Keputusan Pembelian. E-Jurnal Manajemen Unud, 6(8), 4538-4568.

Ering, M. C., \& Pandowo, M. (2015). Analysis of Marketing Communication and Its Effect on Consumer Purchase Intentions of Gold Metal At PT. Pegadaian (Persero) Manado Utara Branch. Jurnal EMBA, 3(2), 776-786.

Fenanda, Z. I., \& Solekah, N. A. (2018). Analisis Pengaruh Word Of Mouth Terhadap Keputusan Nasabah Untuk Menabung Dengan Brand Equity Sebagai Variabel Mediasi. Journal of Chemical Information and Modeling, 


\section{4, 103-122. https://doi.org/10.1017/CBO9781107415324.004}

Hamza, V. K., \& Rahul, G. (2017). Mediation of Brand Equity on Word of Mouth: A Study with Special Reference to Customers of Fashion Products in India. Advances in Management, 10(10), 23-29.

Harsa, R. S., \& Syahputra. (2015). Pengaruh Brand Equity Game Mario Terhadap Minat Beli Konsumen Nintendo Indonesia Pada Konsol Nintendo (Studi pada komunitas Nintendo Indonesia). E-Proceeding of Management, 2(2), 2105-2116.

Indriani, E. (2017). Strategi Komunikasi Pemasaran Terpadu Untuk Meningkatkan Ekuitas Merek Solopos.

Khan, S. A., Ramzan, N., Shoaib, M., \& Mohyuddin, A. (2015). Impact Of Word Of Mouth On Consumer Purchase Intention. 479-482. https://doi.org/10.4018/978-1-4666-9449-1.ch012

Malino, S. B. (2015). Pengaruh Country Of Origin Dan Word Of Mouth Terhadap Dimensi Brand Equity Dan Pengaruh Dimensi Brand Equity Terhadap Brand Equity Smartphone Samsung Di Surabaya. Jurnal Ilmiah Mahasiswa Universitas Surabaya, 4(2), 1-11.

Mirabi, V., Akbariyeh, H., \& Tahmasebifard, H. (2015). A Study of Factors Affecting on Customers Purchase Intention Case Study: the Agencies of Bono Brand Tile in Tehran. Journal of Multidisciplinary Engineering Science and Technology (JMEST), 2(1), 267-273.

Moniaga, N. A., Paputungan, R., \& Kalangi, J. S. (2017). Pengaruh Komunikasi Pemasaran Terhadap Minat Beli Produk Pt. Indofood Cbp Sukses Makmur Bitung. E-Journal “Acta Diurna,” VI(1).

Ogbeide, D., \& Omoregbe, O. (2017). Brand Equity and Purchase Intentions among Mobile Phone users in Benin City. Lapai Journal of Management Science, 7(2), 243-255.

OPPO. 2013. About Oppo. Website: https://www.oppo.com/id/about-us/. Diakses pada 19 Mei 2019.

Prabowo, I. J. K. G., \& Nurhadi. (2016). Pengaruh Citra Merek, Kualitas Produk, Persepsi Harga Dan Word Of Mouth Terhadap Minat Beli (Studi pada Mahasiswa Fakultas Ekonomi UNY Pengguna iPhone). 246-256. Retrieved from http://journal.student.uny.ac.id/ojs/ojs/index.php/jmbi/article/view/5028

Prawira, B., \& Yasa, N. N. K. (2014). Pengaruh Kualitas Produk, Citra Merek dan Persepsi Harga Terhadap Minat Beli Produk Smartphone Samsung di Kota Denpasar. E-Jurnal Manajemen Universitas Udayana, 3, 3642-3658.

Putri, F. C., Kumadji, S., \& Sunarti. (2016). Pengaruh Word Of Mouth Terhadap 
Minat Beli Dan Dampaknya Pada Keputusan Pembelian ( Survei pada konsumen Legipait Coffeeshop Malang ). Jurnal Administrasi Bisnis (JAB), 34(1), 86-95.

Ramos, A. F. V., \& Franco, M. J. S. (2015). The effects of Marketing Communication on Brand Equity A Look into the Market of Lasting Goods.

Shah, S. M., Adeel, M., Hanif, F., \& Khan, M. (2016). The Impact of Brand Equity on Purchase Intensions with Modertaing Role of Subjective Norms. Universal Journal of Industrial and Business Management, 4(1), 18-24. https://doi.org/10.13189/ujibm.2016.040102

Sulistyowati, D., Lubis, N., \& Listyorini, S. (2014). Pengaruh Periklanan, Hubungan Masyarakat, Dan Word of Mouth Terhadap Ekuitas Merek Sepeda Motor Matic Honda Vario. Jurnal Ilmu Administrasi Bisnis.

Top Brand Index. 2019. Top Brand Index Kategori Lengkap. Website: www.topbrandaward.com. Diakses 11 April 2019.

Viliaus, C., \& Tobing, R. L. (2017). Pengaruh Komunikasi Pemasaran Terpadu Terhadap Minat Beli Konsumen Pond's Yang Dimediasi Oleh Brand Equity. Jurnal Manajemen Bisinis, 12(2), 129-142.

Walangitan, A., Pangemanan, S., \& Rumokoy, F. (2015). Analysing the Impact of Brand Equity on Consumer Purchase Intention of Etude House Cosmetic Product in Manado. Jurnal Riset Ekonomi, Manajemen, Bisnis Dan Akuntansi, 3(2), 758-766.

Wong, M.-C. M., Kwok, M.-L. J., \& Lau, M. M. (2015). Spreading Good Words: The Mediating Effect of Brand Loyalty between Role Model Influence and Word of Mouth. Contemporary Management Research, 11(4), 313-326. https://doi.org/10.7903/cmr.13838

Younus, S., Rasheed, F., \& Zia, A. (2015). Identifying the Factors Affecting Customer Purchase Intention. Global Journal of Management and Business Research: A Administration and Management, 15(2). https://doi.org/10.1111/j.1365-2621.1940.tb17194.x

Zaynutdinova, N., \& Premysl, P. (2017). The Effects on Purchase Intention: The Case of Fruit Juice. Journal of Competitiveness, 9(3), 111-128. https://doi.org/10.7441/joc.2017.03.08 